\title{
1 New Perspectives on Social and Educational Reform during the Long Nineteenth Century. An Introduction
}

This book is the first volume of a new academic series devoted to the results of scientific workshops and colloquia organised by Liberas/Liberaal Archief, the central archive and documentation centre of the liberal movement in Belgium/ Flanders. ${ }^{1}$ On 10 February 2017, the institution organised an academic workshop on $19^{\text {th }}$-century social and educational reform movements. This topic connects well with the expertise and collection of Liberas/Liberaal Archief on reformist and educational initiatives set up by social or progressive liberals in Flanders. The largest part of this volume consists of a multifaceted selection of studies presented at the colloquium. ${ }^{2}$ All contributions explore an array of $19^{\text {th }}$-century bourgeois initiatives in Belgium that tried to solve the 'social question' by 'civilising' and moralising the lower classes. 'Social reform' refers to a wide variety of efforts taken by an engaged elite to deal with the social question. The concept of the 'social question', in its turn, became in vogue from the 1880s onwards. It is a catch-all term used to describe a wide set of problems related to the processes of urbanisation and industrialisation, which led to extremely poor living conditions for the urban and industrial proletariat. Social problems were related to crime, deviancy, public health, hygiene and their moral side effects. ${ }^{3}$ Hence, educational reform initiatives can not be set apart from the social question, as education was considered to be one of the most efficient instruments for reform.

1 See: www.liberas.eu.

2 Both the colloquium and this publication were made possible thanks to the continuous support of Peter Laroy, Director of Liberas/Liberaal Archief, and the efforts of all those who presented and discussed papers at the colloquium. I would like to thank all the authors who submitted chapters for this book for their time and patience, as well as the reviewers for their valuable comments and suggestions. A special word of thanks goes to Rabea Rittgerodt at De Gruyter Oldenbourg for her commitment and guidance.

3 Chris Leonards and Nico Randeraad, "Transnational Experts in Social Reform, 1840-1880," International Review of Social History 55, no. 2 (2010): 219.

Ә OpenAccess. () 2019 Christoph De Spiegeleer, published by De Gruyter. (cc) BY-NC-ND This work is licensed under the Creative Commons Attribution-NonCommercial-NoDerivatives 4.0 License. 


\section{Civilising offensive, educationalisation and social legislation}

Through a number of concrete case studies, all chapters in this volume contribute to a better understanding of the mechanisms behind the $19^{\text {th }}$-century 'bourgeois civilising offensive'. In the late 1970s-early 1980s, Dutch historians coined the term 'the bourgeois civilising offensive' ("het burgerlijk beschavingsoffensief"). This referred to $19^{\text {th }}$-century middle-class attempts to improve the fate of the lower classes, and 'raise' them to a higher, 'civilised' standard of conduct. Initiatives ranged from model factory villages to educational and recreational activities and health campaigns. ${ }^{4}$ The term was inspired by the work of Norbert Elias on the civilising process, ${ }^{5}$ Michel Foucault's study ${ }^{6}$ on the disciplining of the body, and Christopher Lach's book ${ }^{7}$ on forces of organised virtue during the $19^{\text {th }}$ century.

The core of the Western civilising process is, in the judgment of Elias' theory, a long-term development in emotion management, an increasing tendency towards self-control that started in the upper strata of society (in the Ancien Régime the nobility, in the $19^{\text {th }}$ century the bourgeoisie) and spread over wider layers of the population through distinction and imitation. Elias' civilisation theory permits little socio-historical differentiation and constitutes only one side of the history of educational and social reform, thereby neglecting the actual effects and impact of these external civilising forces on individuals. ${ }^{8}$ The same goes

4 For the first uses of the term, see: Piet de Rooy, Werklozenzorg en werkloosheidsbestrijding 19171940. Landelijk en Amsterdams beleid (Amsterdam: Van Gennep, 1979); Bernard Kruithof, "De deugdzame natie. Het burgerlijk beschavingsoffensief van de Maatschappij tot Nut van 't Algemeen tussen 1784 en 1860,” Symposion. Tijdschrift voor maatchappijwetenschap 2, no. 1 (1980): 22-37. For a reconstruction of the intellectual context in which the concept was born in the Netherlands, see: Ali de Regt, "Beschavingsoffensief (civilising offensive): from Sociological Concept to Moral Appeal," Human Figurations 4, no. 1 (2015); Bernard Kruithof, "The Dutch Bourgeois Civilising Offensive in the Netherlands," Human Figurations 4, no. 1 (2015) (accessible via https://quod.lib.umich.edu/h/ humfig/11217607.0004.1*?rgn=main;view=fulltext). For an overview of the various ideas and initiatives of late $19^{\text {th }}$-century Dutch reformers against an international background, see: Christianne Smit, De volksverheffers. Sociaal hervormers in Nederland en de wereld, 1870-1914 (Hilversum: Verloren, 2015). 5 See: Norbert Elias, Über den Prozess der Zivilisation (Berlin: Suhrkamp, 1976 [1939]); de Regt, "Beschavingsoffensief (civilising offensive)".

6 Michel Foucault, Surveiller et punir: Naissance de la prison (Paris: Gallimard, 1975).

7 Christopher Lash, Haven in a Heartless World. The Family Besieged (New York: Basic Books, 1977).

8 One could argue that the concept 'bourgeois civilising offensive' does not fit with Elias' civilisation theory. Elias regards the civilising process as an unintended, unplanned social develop- 
for the normalising paradigm of Michel Foucault, where hospitals, prisons, factories and schools exert disciplinary power over the individual, making no distinction between disciplining strategies and the actual effects of these interferences. ${ }^{9}$ The concept of 'bourgeois civilising offensive' has gone somewhat out of use because of its association with a one-sided top-down interpretation of the history of social and educational reform, with a focus on disciplinary interests of reformers. ${ }^{10}$ Even though few authors in this volume still explicitly use the term, a lot of the case-studies analysed here address various ambiguities of $19^{\text {th }}$. century civilising activities and initiatives of bourgeois reformers, in particular with regard to their effects and target groups. Together they allow for a less one-sided take on the $19^{\text {th }}$-century 'bourgeois civilising offensive'.

When studying the $19^{\text {th }}$-century 'bourgeois civilising offensive', we have to take into account various nuances. First, although the term 'civilising offensive' has a military and disciplining connotation, this does not exclude the benevolent intentions of many reformers, as well as the fact that the new rules and behavioural standards were often in accordance with the wishes and interests of the working-class families concerned, without necessarily being coercive. This does not imply that the labouring poor were a blank slate without a culture and behavioural norms of their own. When using the concept of 'civilising offensive', we should leave room for failed effects of civilising strategies, caused by resistance or indifference. Due to a lack of sources, it is difficult to measure the effects and perceptions of the civilising offensive among the lower classes. ${ }^{11}$ Second, it is important to note that 'elevating' the lower classes was not meant to make them the equals of the bourgeoisie. Social barriers were not to be broken down and keep-

ment, whereas the bourgeois civilising offensive was an intendend and planned initiative to change the behaviour of lower groups. However, though the civilisation process as a whole is unplanned, during that process dominant groups still take specific actions to civilise lower strata towards more disciplined behaviour and self-control. These attempts were part of a more general civilising process that resulted from growing interdependencies between social groups. See: de Regt, "Beschavingsoffensief (civilising offensive)".

9 Marc Depaepe, "Educationalisation: A Key Concept in Understanding the Basic Processes in the History of Western Education," History of Education Review 27, no. 1 (1998): 19 - 22.

10 For a critical appraisal of the concept 'civilising offensive' and Elias' theory, see: Jeffrey Tyssens, "Het Willemsfonds als sociaal-culturele organisatie," in Vlaamsch van taal, van kunst en zin. 150 jaar Willemsfonds (1851-2001) (Ghent: Willemsfonds/Liberaal archief, 2001), 185186; Smit, Volksverheffers, 11-13. Nowadays, the term 'civilising offensive' is used in a general, public discourse of moral decline to address problems of indecency and rudeness in public spaces, and a lack of norms and values in general. See: de Regt, "Beschavingsoffensief (civilising offensive)".

11 See: Smit, De volksverheffers; Ali de Regt, Arbeidersgezinnen en beschavingsarbeid. Ontwikkelingen in Nederland 1870-1940 (Meppel: Boom, 1984). 
ing a distance between the bourgeoisie and the common man was still absolutely necessary. The 'civilising offensive' often came with a 'civilising defensive'. This is, for example, shown in chapter 2, which focuses on initiatives aimed at the physical and moral reform of neglected working-class children, who were seen as possible dangers to future society. Chapter 7 on house-building associations stresses the thin line between discipline and humanitarianism, between paternalism and emancipation. Third, various initiatives that were part of this bourgeois civilising offensive did not necessarily reach the poor labour classes (such as the popular restaurants analysed in chapter 6), but offered a way of life to intermediary groups such as the 'better' skilled workers and the petty bourgeoisie, which would serve as examples for the lower groups. ${ }^{12}$

It is also important to note that the actions and initiatives instigated by reformers often had a multidimensional character. An example of an early $20^{\text {th }}$. century social housing project that combined strategies of social and educational reform was the urban renewal program of the Istituto Romani di Beni Stabiliti. The Roman real estate association, founded in 1904, was engaged in the rehabilitation of housing in a depressed slum area in Rome by acquiring and re-modeling run-down city tenements. In 1907, the director general of the society, Eduardo Talamo (1858-1916), gave Italian pedagogue Maria Montessori (1870-1952) the opportunity to open a school in a large tenement house. The Casa dei Bambini welcomed poverty-affected children, from age three to seven. Montessori used the school to test and verify her educational theories. ${ }^{13}$ Whereas Montessori wanted to develop an innovative pedagogical method based on the principle of auto-education, Talamo regarded the schools of the Instituto Romani di Beni Stabiliti first and foremost as part of a larger civilising and moralising offensive towards the poor tenants. Talamo also had to protect the financial interests of the real estate association's shareholders. Talamo and Montessori eventually parted ways in $1909 .{ }^{14}$

12 Bernard Kruithof, “'Godsvrucht en goede zeden bevorderen'. Het burgerlijk beschavingsoffensief van de Maatschappij tot Nut van “t Algemeen," in Tot burgerschap en deugd. Volksopvoeding in de negentiende eeuw, eds. Nelleke Bakker e.a. (Hilversum: Verloren, 2006), 78-79; Jean Puissant, "Quelques aspects de la moralisation de la classe ouvrière au XIXme siècle," Réseaux. Revue interdisciplinaire de philosophie morale et politique 32-34 (1978): 78.

13 Gerald Lee Glutek, "Introduction," in The Montessori Method. The Origins of an Educational Innovation: Including an Abridged and Annotated Edition of Maria Montessori's The Montessori Method (Oxford: Rowman \& Littlefield Publishers, 2004), 14-17.

14 Renato Foschi, "Maria Montessori e la prima Casa dei Bambini dell'Istituto Romano di Beni Stabili (1970)," Giornale di Storia Contemporanea 10, no. 2 (2007): 160 - 175. 
Many bourgeois or middle-class reformers gave a key role to education and socialisation to solve the social question. Initiatives to elevate the people morally were bound up with an increased attention on the pedagogical sphere. ${ }^{15}$ In the late 1990s, historical educationalist Marc Depaepe propagated building on the notion of 'educationalisation', which was to be further filled in historically, as an alternative to the 'civilisation' and 'normalisation' paradigms within educational historiography. ${ }^{16}$ In the 1980s and 1990s, Belgian pedagogues and educational historians began to use the term 'educationalisation' (or 'pedagogisation') as an umbrella word to indicate the steady expansion and increased depth of educational action during the $19^{\text {th }}$ and $20^{\text {th }}$ centuries. ${ }^{17}$ These scholars understood 'educationalisation', from the German word "Pädagogisierung"18, as the quantitative and qualitative expansion of the domain of educational/pedagogical theory and practice to numerous areas of everyday life.

In Belgium, progressive parts of the liberal bourgeoisie were at the vanguard of the educationalisation of the daily world of the workers and the broader civilising offensive. Nineteenth-century reformist and educational initiatives set up by social or progressive liberals ("progressistes") have been the subject of research by both historians and pedagogues active in the field of history of educa-

15 Marc Depaepe, Frederik Herman, Melanie Surmont, Angelo Van Gorp and Frank Simon, "About Pedagogization: From the Perspective of the History of Education," in Between Educationalization and Appropriation: Selected Writings on the History of Modern Educational Systems, ed. Marc Depaepe (Leuven: Leuven Univeristy Press, 2012), 190; Frank Simon and Dirk Van Damme, "De pedagogisering van de kinderlijke leefwereld. De "Ligue de l'Enseignement" en de oorsprong van enkele para-scolaire initiatieven," in Rechten van kinderen. Een tekstbundel van de Rijksuniversiteit Gent naar aanleiding van de Uno-Conventie voor de Rechten van het Kind, eds. Eugène Verhellen e.a. (Antwerp: Kluwer, 1989), 157, 166; Jean Puissant, "Quelques aspects de la moralisation de la classe ouvrière au XIXme siècle," 67-81.

16 Marc Depaepe, "Educationalisation: A Key Concept," 22.

17 Depaepe, Herman, Surmont, Van Gorp and Simon, “About Pedagogization,” 178-179. See, for example: Maria Bouverne-De Bie, "De pedagogisering van sociale problemen. Historische ontwikkelingen in de jeugdwelzijnszorg in Vlaanderen," Tijdschrift voor Sociale Wetenschappen 36, no. 1 (1991): 1-15; Simon and Van Damme, "De pedagogisering van de kinderlijke leefwereld," 151-181.

18 The concept 'Pädagogisierung' was coined in the late 1950s to the 1960s, but only gained some popularity in German pedagogical historiography in the 1980s. See: Ulrich Herrmann, "Die Pädagogisierung des Kinder- und Jugendlebens in Deutschland seit dem ausgehenden 18. Jahrhunderts," in Zur Sozialgeschichte der Kindheit, eds. Jochen Martin and August Nitschke (Freiburg: Alber, 1986), 661-683. Authors translate "Pädagogisierung” as both 'educationalisation' and 'pedagogisation'. We prefer 'educationalisation'. 
tion in Belgium. ${ }^{19}$ Like elsewhere in Europe, the Belgian Liberal Party was divided between a progressive and a conservative wing. Left-wing progressive or social liberals influenced the rise of socialism. ${ }^{20}$ Progressive liberals were in favour of a positive stimulating role for the government to end strong social and economic inequalities, but disagreed on the exact extent of desirable state intervention in the social question. ${ }^{21}$ With regard to social politics, these progressistes clearly differed from conservative liberals. They propagated measures to benefit workers and extend suffrage. They also built bridges with the labour movement. Social liberals claimed that the worker was socially inferior because he was intellectually inferior. Instead of class segregation, they strived for integration, which would ease the fear of the upper classes and avoid workers turning into dangerous collectivists or anarchists. ${ }^{22}$ Secularised education was a major pillar

19 Marc Depaepe, De pedagogisering achterna. Aanzet tot een genealogie van de pedagogische mentaliteit in de voorbije 250 jaar (Leuven/Amersfoort: Acco, 1999), 176-177. For the role of the Ligue de l'Enseignement, see: Simon and Van Damme, "De pedagogisering van de kinderlijke leefwereld," 151-181. For an overview of liberal francophone associations which offered popular education (conferences, distribution of books, popular libraries, excursions) to the working classes between 1860 and 1880, see: Jacques Lory, "Les Sociétés d'éducation populaire de tendance libérale 1860-1880,” Belgisch Tijdschrift voor Nieuwste Geschiedenis 10, no. 1-2 (1979): 217-254. The influence of progressive liberals in the 1860s and 1870s was important for the growth of these societies. Lory compared the following societies: Soirées Populaires in StJosse-ten-Node (1863), the Ligue de l'Enseignement (1864), the Société Franklin in Liège (1865), and the Cercle des Réunions Populaires de Mons et du Hainaut (1876). For an overview of the activities of the branches of the Willemsfonds concerning popular education in Flanders and Brussels, see: Luc Pareyn, "Het Willemsfonds en de volksontwikkeling," in Het Willemsfonds van 1851 tot 1914 (Ghent: Provinciebestuur Oost-Vlaanderen, 1993), 185-223. See also: Catharina Lis, Hugo Soly and Dirk Van Damme, Op vrije voeten? Sociale politiek in West-Europa (1450 - 1914) (Leuven: Kritak, 1985), 179-180.

20 Carl Strikwerda, A House Divided. Catholics, Socialists and Flemish Nationalists in NineteenthCentury Belgium (Lanham: Rowman \& Littlefield Publishers, 1997), 32. For an overview of the political translation of social liberal ideas in the Netherlands, Britain and Germany around 1900, see: Fleur de Beaufort and Patrick Van Schie, Sociaal-liberalisme (Amsterdam: Boom, 2014), 111-148.

21 Carmen Van Praet, "Liberale hommes-orchestres en de sociale kwestie in de negentiende eeuw. Tussen lokaal en internationaal” (PhD. diss., University Ghent, 2015), 375; René Vermeir and Jeffrey Tyssens, Vrijmetselarij en Vooruitgang. De Gentse progressistenloge La Liberté (1866-1966) (Brussels: ASP Editions, 2016), 140.

22 Els Witte, Jan Craeybeckx and Alain Meynen, Political History of Belgium from 1830 onwards (Brussels: ASP Editions, 2009), 78. For a reconstruction of the political culture shared by Brussels progressistes during the second half of the $19^{\text {th }}$ century, see: Christoph De Spiegeleer, "Charles Potvin (1818-1902) en de progressistische politieke cultuur," Revue Belge de Philologie et de Histoire 91, no. 2 (2013): 387-425. For a study of the way the Ghent progressiste Masonic 
of the progressive liberal plans to solve the social question. When in 1879, a liberal Belgian government enacted a new primary school law that undermined the role of the Church in public elementary schools, the progressive liberal Ligue de l'Enseignement had already been active for years as a pressure group for a new primary school law. ${ }^{23}$ Chapter 5 of this volume explores the difficulties with which the local circles of this educational reform association, which tried to promote popular adult education through libraries and conferences, were confronted.

The importance of the progressive liberal belief in popular secular education as a means to moral and intellectual elevation of the working classes can also be seen in the organisation of the first holiday colonies by liberal philanthropic organisations in the late $19^{\text {th }}$ century, supported by liberal municipal authorities. ${ }^{24}$ In these colonies, weak and poor schoolchildren spent their time playing and walking in the open air to strengthen their fragile health. ${ }^{25}$ Some evolved into permanent school colonies, such as the 'open-air school' of the Diesterweg Hulpkas voor Behoeftige Schoolkinderen ('Diesterweg Assistance Fund for Needy Schoolchildren') in Heide-Kalmthout, where intellectual education took place outside the classroom in the open air. ${ }^{26}$ In 1904, the permanent school colony of this left-liberal education association officially opened its doors to children from Antwerp municipal schools. Initiatives such as these showed the expansion of the medical and pedagogical argument beyond the boundaries of the traditional school environment. ${ }^{27}$

The process of educationalisation not only consisted of an increasing number of child-rearing institutions and educational programs but was also related

lodge La Liberté tried to solve the social question through concrete philanthropic initiatives, see: chapter 5 in René Vermeir and Jeffrey Tyssens, Vrijmetselarij en Vooruitgang.

23 See: Histoire de la Ligue de l'Enseignement et de l'Éducation ermanente, 1864-1989 (Brussels: Ligue de l'Enseignement, 1990).

24 Simon and Van Damme, "De pedagogisering van de kinderlijke leefwereld," 151-181; Martine Vermandere, We zijn goed aangekomen! Vakantiekolonies aan de Belgische kust (18871980) (Brussels/Ghent: ASP Editions/AMSAB, 2010), 23-29, 40-48. In 1878, the Ligue de l'Enseignement already tried to establish its own holiday colony for weak and poor children.

25 See: Vermandere, We zijn goed aangekomen!.

26 Simon and Van Damme, "De pedagogisering van de kinderlijke leefwereld," 165.

27 Geert Thyssen and Marc Depaepe, "The Sacralization of Childhood in a Secularized World: Another Paradox in the History of Education? An Exploration of the Problem on the Basis of the open-air school Diesterweg in Heide-Kalmthout," in Between Educationalization and Appropriation, 89-117. Liberas/Liberaal Archief stores archives of the Diesterweg Assistance Fund for Needy Schoolchildren. The permanent school colony in Heide-Kalmthout continued to function till 1963. 
to the increasingly central role of the pedagogical in society. The 'educational gaze' also manifested itself in domains and initiatives that did not originally belong to the professional fields of teachers and educators. ${ }^{28}$ For example, we can see a growing pedagogisation of penal punishment of juvenile delinquents, in which prisons were becoming schools and prisoners were becoming pupils, in successive denominations of the St.-Hubert prison for juvenile (male) offenders. This prison for male minors, the first in Belgium, opened its doors in 1844. In 1867, it became a "maison pénitentiaire et de réforme", and in 1881, the prison was turned into a "maison special de réforme", leaving behind every explicit textual reference to the penitentiary and penal character. ${ }^{29}$

Children were not the only people who were subjected to the influence of educationalisation and civilising offensives. Chapters 6 and 7 stress how ideas of moral uplift and practical instruction were present in reformist initiatives sponsored by reformers and associations such as "cités ouvrières modèles", 'model housing quarters', and “fourneaux économiques”, 'people’s kitchens'. Reformers integrated down-to-earth activities such as working in the small garden of one's own house, or eating in a cheap popular restaurant, in the broader perspective of the moralisation and civilisation of the working classes. It was believed that maintaining gardens in model workers' quarters of mid-century house building associations would keep labourers away from pubs and other immoral places. The food culture of cheap restaurants instigated by Dutch and Belgian social reformers was also explicitly presented as an alternative to drinking joints, with strict behavioural guidelines. Hence, both gardens and dining halls became informal educational spaces within the bourgeois civilising offensive.

"Visiteurs du pauvre" and rent collectors active in various European cities intervened in the personal living spaces of worker families and regarded the houses of the working classes as educational spaces within the civilising offensive. Already in Joseph-Marie de Gérando's 1824 study on philanthropy as an empirical science, Le visiteur du pauvre, the French philanthropist stressed the importance of personal visits to check the cleanliness and orderly state of the interiors in which the poor lived as signs of their moral condition. ${ }^{30}$ In the 1860 s, the influential English social reformer Octavia Hill (1838-1912) began what was referred to as 'friendly rent collecting' in a London slum. Hill and her assistants not

28 Depaepe, Herman, Surmont, Van Gorp and Simon, “About Pedagogization,” 178-179.

29 Jenneke Christiaens, "A History of Belgium's Child Protection Act of 1912. The Redefinition of the Juvenile Offender and his Punishment," European Journal of Crime, Criminal Law and Criminal Justice 7, no. 1 (1999): 8.

30 Michel Perrot, “L'Oeil du baron ou le visiteur du pauvre," in Du visible à l'invisible. Pour Max Milner, ed. Stéphane Michaud (Paris: José Corti, 1988), 63-71. 
only managed the buildings but also the tenants, and taught them lessons of self-help and self-reliance through personal contacts and inspections. Hill believed that families could learn and develop the necessary norms and values in their house under the right circumstances. ${ }^{31}$ This professional $19^{\text {th }}$-century social work discourse of individual help for the 'deserving' poor proved to be an enduring legacy in social work, extending into the $20^{\text {th }}$ century. ${ }^{32}$

Aside from offering a better understanding of broader epochal processes such as educationalisation and civilising offensives, a close study of the efforts of social and educational reformers that dealt with the social question before the widespread emergence of social legislation helps us understand how welfare states are historically grown constructs, which have been long in the making. When in the 1980s Dutch social scientists began to use the term 'civilising offensive', they used it to refer to middle-class initiatives that sooner or later changed into a form of state intervention, be it in the domain of poor relief, child protection, unhealthy housing, prison life or infant care. ${ }^{33}$ In fact, the expertise and authority of reformers left their imprint on the formation of (later) social legislation, although the road was often long and direct influence is not always easy to trace. For example, Octavia Hill helped pressure the British government into passing the Artisans' and Labourers' Dwellings Improvement Act in 1875. The act permitted local councils to buy up areas of slum dwellings in order to clear them. ${ }^{34}$

Regulations of the industrial labour process and measures to educate and ensure the welfare of children were enacted into law in many industrialising capitalist nations during the late $19^{\text {th }}$ and early $20^{\text {th }}$ centuries. Politicians often built on the practical blueprints initiated by the (private or mixed private/public) actions of reformers, through organisations such as housing associations, educational societies and co-operative societies, and with the help of the production of knowledge through the exchange of ideas and expertise of intellectual elites on international fora. Knowledge-bearing groups and knowledge-generating institutions influenced the framing of issues, and helped identify and characterise

31 For the international influence of Hill, see: Smit, Volksverheffers, 156-165.

32 John Harris, "State Social Work: Constructing the Present from Moments of the Past," British Journal of Social Work 38, no. 4 (2008): 666.

33 See: de Regt, "Beschavingsoffensief (civilising offensive)".

34 Ken Blakemore and Louise Warwick-Booth, Social Policy. An Introduction. 4th edition (Maidenhead: Open University Press, 2013), 235. 
social problems associated with the effects of capitalist industrialisation on which states could act. ${ }^{35}$

Each state has its own historical trajectory of social legislation. ${ }^{36}$ In Belgium, the 1880s were particularly stirring years. The riots and strikes of March 1886 shook bourgeois society out of its complacency and instigated a first wave of social legislation. The years 1886-1914 witnessed a considerable growth of social legislation, and the Belgian state, social policies and previously produced social knowledge became intimately intertwined. ${ }^{37}$ Take, for example, social laws on housing (1889) and child protection (1912), two topics treated in different contributions in this volume. In 1889, the Catholic government promulgated a law on the housing of labourers. Building houses for the poor became a task of housebuilding associations, which could borrow money from a national savings bank. Although this law came into being as a reaction to the social upheavals of 1886 , the government could rely on a long tradition of reflection and private initiatives regarding social housing. ${ }^{38}$ In 1887, the High Council for Public Hygiene pointed out the fact that "illuminated minds have been insisting for a long time that it is necessary to create rural dwellings, near the industrial centres, where the workers can enjoy clean air, a cheap life and rest". ${ }^{39}$ The central goal of the 1889 housing law was the integration of workers by turning them into house owners living in the surroundings of urban centres, without the direct intervention of the national government. This idea had already been spread transnationally in the 1850 -1860s, and resembled the Mulhouse Model. Furthermore, as shown in chapter 7, the latter had already inspired small-scale housing projects in Belgium in the 1850 s and 1860s.

The Belgian Child Protection Act of 1912, which brought the problem of juvenile offenders, abandoned children and educational or social surroundings into one legal frame, also did not come out of nowhere. It was based on the decades

35 Theda Skocpol and Dietrich Rueschemeyer, “Introduction," in States, Social Knowledge, and the Origins of Modern Social Policies, eds. Dietrich Rueschemeyer and Theda Skocpol (Princeton: Princeton University Press/New York: Russell Sage Foundation, 1996), 3-13

36 See: Lis, Soly and Van Damme, Op vrije voeten?, 182-197.

37 Gita Deneckere, "Nieuwe Geschiedenis van België, 1878-1905," in Nieuwe Geschiedenis van België. Deel I. 1830-1905 (Tielt: Lannoo, 2005), 565-577.

38 Van Praet, "Liberale hommes-orchestres," 69-70.

39 Cited in Pascal De Decker, "A Garden of Eden? The Promotion of the Single-Family House with a Garden in Belgium before the Second World War," in The Powerful Garden: Emerging Views on the Garden Complex, eds. Valerie Dewaelheyns, Kirsten Bomans and Hubert Gulinck (Antwerp: Garant, 2011), 38. 
old 'social defence doctrine'40, as proposed and defended at international congresses by Adolphe Prins (1845-1919), professor of penal law (1876-1919) and general inspector of prisons (1887-1917), and other experts in the new science of criminology. ${ }^{41}$ The idea of social defence implied an intensified search into pre-delictual situations. In doing so, it reserved a key role for child protection in an all-embracing quest to prevent (future) crimes. ${ }^{42}$ Prins inspired the legislative actions of Jules Lejeune (1828-1911), Minister of Justice between 1887 and 1894, including the introduction of the first Belgian project for a child protection act in 1889, which provided the blueprint for the law of $1912 .{ }^{43}$

In the remainder of this brief introduction, we will sketch the general historical context of social and educational reform in Belgium, focusing on the particularities of Belgian history which explain why Belgium is such a 'great small nation' to conduct research into social and educational reform, followed by a closer look at the role of the city of Ghent as a 'social laboratory'. We conclude by setting out the general outline of the volume and position the various chapters in the context of international historiography.

\section{Social and educational reform in nineteenth-century Belgium}

All chapters in this book start from Belgian initiatives and reformers, or the impact of foreign reform models on Belgian soil, to highlight various middle-class attempts at improving the fate of the lower classes. Chapters 6 and 8 explicitly focus on parallels and differences between Belgium and the Netherlands. All contributions are proof of a considerable amount of recent scholarly interest in social and educational reform in $19^{\text {th }}$-century Belgium, both among historians and among pedagogues specialised in the history of education. We identify three main reasons why Belgium is such a 'great small country' for the exploration of social and educational reform as a response to the social question in Europe: (1)

40 See: Françoise Tulkens, Généalogie de la défense sociale en Belgique (1880-1914). Travaux du séminaire qui s'est tenu à l'Université Catholique de Louvain sous la direction de Michel Foucault (Brussels: Story-Scientia, 1988).

41 Stef Christiaensen, Tussen klassieke en modern criminele politiek (Leuven: Universitaire Pers Leuven, 2004), 502-503.

42 Christiaens, "A History of Belgium's Child Protection Act," 16-17.

43 Marie-Sylvie Dupont-Bouchat, Les pénitenciers pour les enfants en Belgique au XIXe siècle (1840-1914) (Louvain-la-Neuve: Commission internationale pour l'histoire des Assemblées d'États, 1996), 55-64, 91-97. 
late $19^{\text {th }}$-century Belgium was a heavily industrialised state, with long hours and low wages, (2) from the mid-century until the Belle Époque, Belgium was an important site of internationalism/transnational intellectual exchange of ideas for solving the social question, and (3) the analysis of reformist initiatives enables us to gain insights into various national zones of tension in Belgian history. Let us take a closer look at these three elements.

First, around 1850, Belgium was continental Europe's most heavily industrialised state. ${ }^{44}$ It was the first nation on the European mainland to experience accelerated industrialisation during the first half of the century. Like Britain and Germany, its industrial base rested on coal, metallurgy and textiles. Until the 1880s, Belgium was second only to Britain as an industrialised country. Although Belgium's industrialisation closely followed the British model, its standards of living were worse. For most of the century, the densely populated country was able to stay competitive on world export markets by virtue of its cheap labour costs, which in turn were heavily dependent on women and children's labour, with widespread poverty and a low standard of living as a consequence. ${ }^{45}$ For the majority of the $19^{\text {th }}$ century, the national state mostly served as a regulating power in the social field, without any direct involvement in its organisation. Social provisions such as social housing and poor relief were (in theory) the responsibility of local governments but actually largely depended on private welfare providers such as religious institutes and philanthropic societies, which lead to various types of private/public cooperation. ${ }^{46}$ In 1914 , Belgium was the last in-

44 The Netherlands, on the other hand, would not begin the industrialisation process in earnest until four decades later. See: Thomas Ertman, "Liberalization, Democratization, and the Origins of a 'Pillarized' Civil Society in Nineteenth-Century Belgium and the Netherlands," in Civil Society Before Democracy: Lessons from Nineteenth-Century Europe, eds. Nancy Bermeo and Philip Nord (Lanham: Rowmand and Littlefield Publishers, 2000), 156.

45 Strikwerda, A House Divided, 35.

46 Hendrik Moeys, "Social Policy by Other Means from a Comparative Historical Perspective. Continuity and Change in Nineteenth-Century Belgium (1800 -1920)," Journal of Comparative Policy Analysis: Research and Practice, no. 1 (2018), https://www.tandfonline.com/doi/full/10. 1080/13876988.2017.1409939; Leen Van Molle, "Social Questions and Catholic Answers. Social Reform in Belgium, c. 1780-1920," in Charity and Social Welfare, ed. Leen Van Molle (Leuven: Leuven University Press, 2017), 104. This can for example be seen in two case studies from the late $19^{\text {th }}$ century explored in chapter 2 . The care for the abandoned children of Ghent was organised through a convention between the religious congegration of the Zusters Kindsheid Jesu and the Council of Civil Hospices. The head of Belgium's first sea hospital in Wenduine (1881), François Van Den Abeele (1824-1900), entered into an agreement with the congregation of the Zusters van de Bermhertigheid Jesu to have a nursing staff at his disposal. See: Vermandere, We zijn goed aangekomen!, $30-31$. 
dustrialised nation to introduce compulsory primary education, from the age of $\operatorname{six}^{47}$

Second, Belgium was not only the most industrialised country on the continent until the late $19^{\text {th }}$ century, it was also an 'international nation' where one could find diverse international associations and an active community of experts who travelled and networked beyond national boundaries. From the mid-century until the Belle Époque, many international social reform associations were based in Belgium, as were their main international actors. ${ }^{48}$ Belgium's geographical position, liberal association laws, well-developed railway network, and the country's linguistic profile (with a prominence of French) benefited its position as an important site of internationalism. ${ }^{49}$ The large number of international congresses held in Belgium between 1840 and 1880 on penitentiary reform, welfare, hygiene, social science and statistics is proof of the country's leading position in the struggle for social reform. ${ }^{50}$ In the 1850 s and 1860 s, ambitious international attempts were launched to solve the social question. In fact, social problems, such as unhygienic houses in industrial cities, did not stop at the borders of the nation-state, sometimes literally, as pandemic diseases spread out transnationally. ${ }^{51}$ The first proper international association for open international debate on social engineering, the Association Internationale pour le Progrès des Sciences, was founded in 1862 by liberals and republicans from across Europe and based in Brussels. Its first four-day congress was held in Brussels in September 1862. Despite its broad thematic scope, the protagonists of the Association Internationale pour le Progrès des Sciences shared an ambition to solve the social question. ${ }^{52}$

Third, the history of social and educational reform in Belgium offers an excellent case for studying the impact of linguistic, philosophical and socio-economic areas of conflict and the resulting segmentation of civil society. As Carl Strikwerda has pointed out, $19^{\text {th }}$-century Belgium provides an especially intriguing example of the road from the industrial revolution to the welfare state, since

47 Stephen K. Sanderson, Modern Societies. A Comparative Perspective (New York: Routledge, 2016), 131-132.

48 Christian Müller and Jasmien Van Daele, "Peaks of Internationalism in Social Engineering: A Transnational History of International Social Reform Associations and Belgian Agency, 1860 1925," Belgisch Tijdschrift voor Filologie en Geschiedenis 90, no. 4 (2012): 1299-1300.

49 Daniel Laqua, The Age of Internationalism and Belgium, 1880-1930: Peace, Progress and Prestige (Manchester: Manchester University Press, 2013), 9.

50 Leonards and Randeraad, "Transnational Experts in Social Reform,” 227.

51 Van Praet, "Liberale hommes-orchestres," 67.

52 Müller and Van Daele, "Peaks of Internationalism,” 1301. 
its politics was complicated by much more than just battles between workers and capitalists. ${ }^{53}$ Well before the rise of socialism, divisions between anticlerical liberals and Catholics had deeply divided Belgian politics. The demands of the industrial revolution, the expansion of education and the political mobilisation of the masses also challenged the privileged place of the French language in Flanders. ${ }^{54}$ Belgium's history is traditionally defined by the presence of three divisions: between Catholics and non-Catholics, between labour and capital, and between Dutch-speakers and French-speakers. The religious-philosophical, the socio-economic and the language dispute had a profound impact on the history of social and educational reform. ${ }^{55}$ From the late $19^{\text {th }}$ century onwards, the institutionalisation of societal divisions led to the compartmentalisation or segmentation of Belgian society in separate ideological (Catholic, liberal and socialist) communities/'pillars', each with its own political and social organisations that catered to all the needs of its members 'from the cradle to the grave'. ${ }^{56}$ Most research on 'pillarisation' in Belgium has focused on the formation of a strong Catholic pillar. ${ }^{57}$ From the late $19^{\text {th }}$-century onwards, Catholic social work consisted of a broad range of activities and associations stimulating self-help and selfdevelopment under strict religious tutelage, such as societies for working-class housing, study circles, temperance societies, women's associations, savings

53 Strikwerda, A House Divided, 27.

54 Strikwerda, A House Divided, 15-36.

55 Luc Huyse, "Breuklijnen in de Belgische samenleving," Als in een Spiegel? Een sociologische kaart van België en Nederland, eds. Luc Huyse and Jan Berting (Leuven: Kritak, 1983), 9-25; Luc Huyse, "Political Conflict in Bicultural Belgium," in Conflict and Coexistence in Belgium. The Dynamics of a Culturally Divided Society, ed. Arend Lijphart (Berkeley: University of California, 1981), 107-126. For the oldest cleavage, the religious-philoshophical divide, see: Els Witte, "The Battle for Monasteries, Cemeteries and Schools: Belgium," in Culture Wars. Secular-Catholic Conflict in Nineteenth-Century Europe, ed. Christopher Clark and Wolfram Kaiser (Cambridge: Cambridge University Press, 2003), 102-128. For a seminal overview of Belgian political history that uses the fault line model to investigate areas of conflict, see: Witte, Craeybeckx and Meynen, Political History of Belgium from 1830 onwards.

56 For comparisons between Belgium and the Netherlands, see: Maarten Van Ginderachter and Minte Kamphuis, "The Transnational Dimensions of the Early Socialist Pillars in Belgium and the Netherlands, c. 1885-1914: An Exploratory Essay,” Belgisch Tijdschrift voor Filologie en Geschiedenis 90, no. 4 (2012): 1321-1337; Ertman, "Liberalization, Democratization, and the Origins of a 'Pillarized' Civil Society".

57 For studies of Catholic pillarisation processes in Belgium within a broader European context, see: Hans Righhart, De Katholieke Zuil in Europa: Een vergelijkend onderzoek naar het ontstaan van verzuiling onder katholieken in Oostenrijk, Zwitserland, België en Nederland (Amsterdam: Boom, 1984); Staf Hellemans, Strijd om de moderniteit: sociale bewegingen en verzuiling in Europa sinds 1800 (Leuven: Universitaire Pers, 1990). 
funds, allotment associations etc. ${ }^{58}$ This process of pillarisation culminated after the First World War.

Even more so than national and international contexts, local socio-economic and municipal cultures decidedly influenced the (early) development of social and educational reform initiatives. A lot of the initiatives and reformers treated in the different contributions to this book were situated in the city of Ghent, in the province of East Flanders. The three characteristics we have identified above, as a way to explain the considerable scholarly interest in Belgian social and educational reform movements (the strong presence of industrialisation, internationalism and societal cleavages/pillarisation of civil society), determined the city's political and cultural history during the long $19^{\text {th }}$ century. Ghent was one of the first cities on the continent to industrialise and it remained an industrial enclave in Flanders throughout the $19^{\text {th }}$ century. ${ }^{59}$ There was an acute shortage of housing, resulting in the typical "cités”or "beluiken"; narrow dead-end streets where the most impoverished part of the population lived in dreary, unsanitary conditions (see Figure 1.1). ${ }^{60}$ Inadequate city dwellings, a lack of personal hygiene, the inability to provide primary necessities such as food and clothing, and unhealthy and dangerous working conditions in the textile factories led to high mortality rates, particularly for infants as a result of bad feeding habits. In other words, Ghent had evolved from a sleepy medieval town to the notorious 'Manchester of the continent' and was in great need of social and educational reform. ${ }^{61}$

Hence, it is no wonder that progressive liberal reformers instigated various associations and initiatives that tried to elevate and educate the Ghent working classes and develop their self-government, with varying degrees of success. For

58 In 1867, the Fédération des Oeuvres Ouvrières Catholiques was founded to co-ordinate and reinforce Catholic patronages and moralising initiatives for workers. This federation preceded the Ligue Démocratique Belge, founded in 1891, which was an umbrella organisation in which various Catholic associations such as workers' circles, cultural assocations, corporatist guilds, co-operative societies etc. joined together on the basis of the same religious belief. See: Van Molle, “Social Questions and Catholic Answers,” 111, 120.

59 Jeroen Backs, "Mortality in Ghent, 1850-1950. A Social Analysis of Death," Belgisch Tijdschrift voor Nieuwste Geschiedenis 31, no. 3-4 (2001): 533

60 Frank Simon and Dirk Van Damme, "Education and Moral Improvement in a Belgian Industrial Town (1860 - 1890). François Laurent (1810 - 87) and the Working Classes in Ghent," History of Education 22, no. 1 (1993): 65.

61 See: Backs, "Mortality in Ghent, 1850 -1950," 529-556. For more information on the wages of Ghent factory workers in the textile industry, see: Peter Scholliers, Wages, Manufacturers and Workers in the Nineteenth-Century Factory. The Voortman Cotton Mill in Ghent (Oxford/Washington: Perg Publishers, 1996). 
example, the first people's bank in Flanders, modelled after the institutions founded by Hermann Schulze-Delitzch (1808-1883) in Germany, saw the light in Ghent in 1866. The Gentsche Volksbank ('Ghent People's Bank'), a credit association established on a cooperative basis with the liberal reformer Gustave Rolin-Jaequemyns (1835-1902) as its president, tried to help the lower classes acquire capital and property by offering credit and saving modalities. The bank loaned mostly start-up capital to traders and craftsmen, and did not reach the poor factory workers of Ghent. The bank in Ghent served as a model for similar institutions in other Flemish cities and remained active until $1905 .{ }^{62}$ Another example of Ghent's rich history of social reform, based on the principles of selfhelp and thrift, was the unemployment fund founded by the city in 1900. The unemployment fund provided municipal financial supplements to individual out-of-work benefits administered by trade unions. This model, devised by Louis Varlez (1863-1930), was soon adopted in cities all over Europe and proved to be crucial in the development of 'subsidised freedom' in social policy at the national level, i.e. the practice of the state granting subsidies to private initiatives that provided social insurance on a voluntary basis. ${ }^{63}$

The city also played an important part in both the first phase of encyclopaedic internationalism during the 1860 s, represented by the Association Internationale pour le Progrès des Sciences Sociales, and the peak of internationalism on social reform during the Belle Époque, with more specialised congresses. ${ }^{64}$ The second large meeting of the Association Internationale pour le Progrès des Sciences Sociales took place in Ghent in $1863 .^{65}$ When at around the turn of the century a new wave of internationalism in social engineering arose, Varlez established the permanent secretariat of the Association Internationale pour la Lutte contre

62 Van Praet, "Liberale hommes-orchestres," 257-271.

63 Jasmien Van Daele, "Louis Varlez en de sociale kwestie: de liberale burgerij uitgedaagd," Handelingen der Maatschappij voor Geschiedenis en Oudheidkunde te Gent 61 (2007): 274-275; Guy Vanthemsche, "La Ville de Gand et l'aide aux chômeurs (1900 -1914). Une innovation communale à résonance nationale et internationale," Revue Belge de Philologie et d'Histoire 89, no. 2 (2011): 889-917; Jo Deferme, Uit de ketens van de vrijheid. Het debat over sociale politiek in België, 1886-1914 (Leuven: Universitaire Pers Leuven, 2007), 338.

64 Müller and Van Daele, "Peaks of Internationalism," 1303.

65 Kathleen Devolder, Gij die door 't volk gekozen zijt ... De Gentse gemeenteraad en haar leden, 1830-1914 (Ghent: Maatschappij voor Geschiedenis en Oudheidkunde, 1994), 157-158. For more info on the meeting in Ghent in 1863, see chapter 9. 


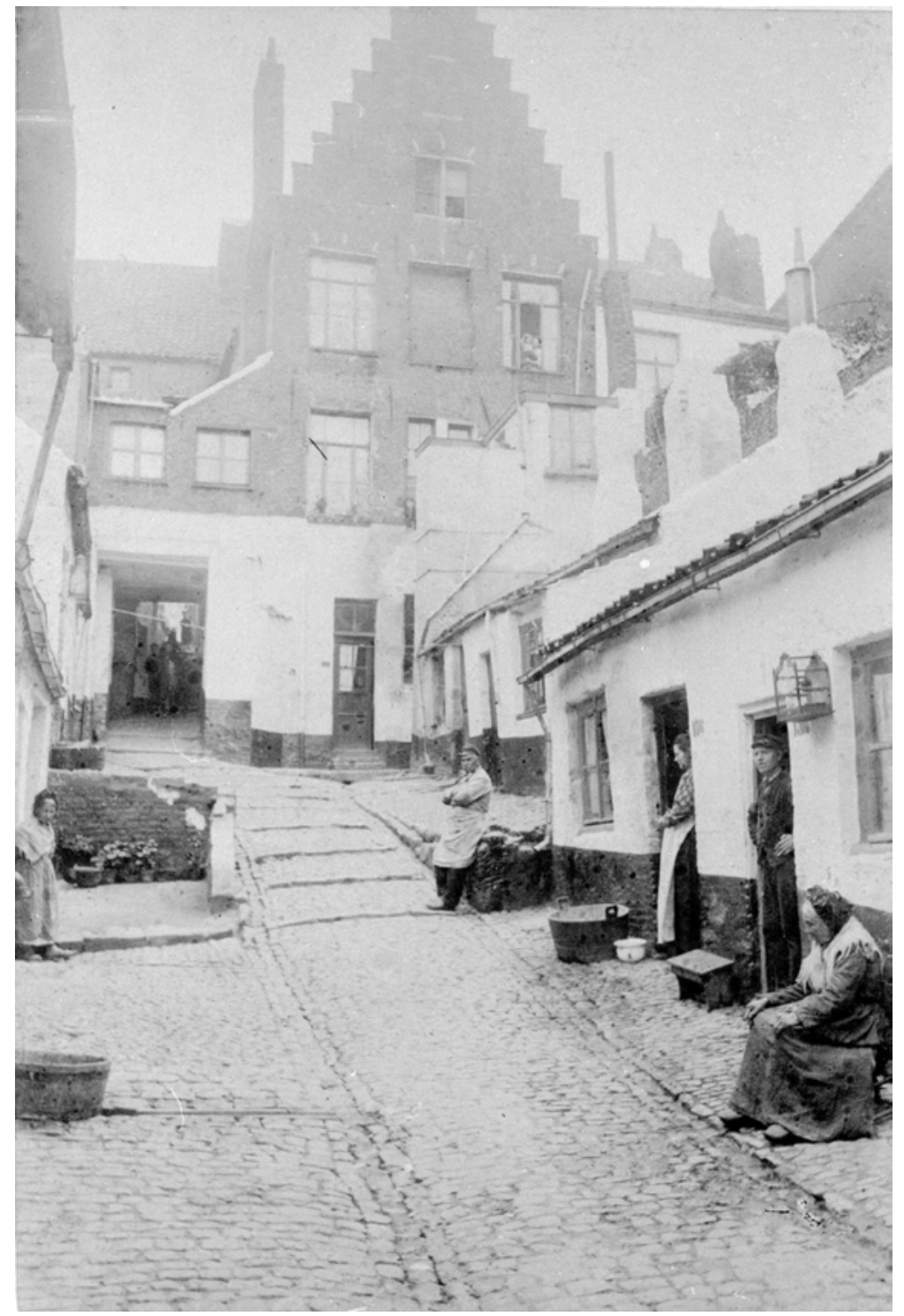

Figure 1.1: Narrow dead-end street in Ghent (beluik) (1900-1950) (๔ University Archives Ghent) 
le Chômage in Ghent in 1911. The city of Ghent hosted the international conferences of this association in 1911 and 1913. ${ }^{66}$

The overlapping zones of tensions in Belgian society we referred to earlier the conflicts between socio-economic groups, between Catholics and non-Catholics, and the language dispute - and the related process of the growing pillarisation of civil society were very much present in the history of social and educational reform in the city of Ghent. The city was a melting pot of liberal, socialist, Catholic and flamingant emancipatory movements. With regard to the language dispute, the Ghent milieu of social liberal reformers sometimes suffered from tensions and concurrence between a francophone and a Flemish-minded/flamingant wing. ${ }^{67}$ The Catholic-secular division ran even deeper into Ghent society. For example, the workers' societies instigated by the anticlerical reformer François Laurent (1810 - 1887), which functioned as evening schools and recreational associations, were liberal counterparts of existing Catholic clubs. Laurent's aim was to keep the pupils of the Ghent adult schools out of the hands of the Church. ${ }^{68}$ Eventually, the first clear beginnings of mass pillarisation in Belgium emerged in late $19^{\text {th }}$-century Ghent. Between the mid-1880s and the late 1890s, Ghent socialists created a socialist 'state within a state' with a network of intertwined organisations such as the consumer cooperative Vooruit ('Forward'), unions, political groups and leisure clubs such as the Gentse Volkskinderen ('The Children of the Popular Classes from Ghent'). ${ }^{69}$ By the early 1890s, a distinctive Catholic working-class movement also emerged in the city, which cop-

66 Jasmien Van Daele, Van Gent tot Genève: Louis Varlez, een biografie (Ghent: Academia Press, 2002), 96 -101; Van Daele, "Louis Varlez en de sociale kwestie: de liberale burgerij uitgedaagd," 278.

67 Van Praet, "Liberale hommes-orchestres," 345; Jacques Lory, Libéralisme et instruction primaire, 1842-1879. Tome 1 (Louvain: Éditions Nauwelaerts, 1979), 350; Het Volksbelang, June 29, 1872, 2.

68 Simon and Van Damme, "Education and Moral Improvement," 77. Liberas/Liberaal Archief stores the archives of two of the most important Laurent's workers' societies which survived till the 1970s.

69 See: Guy Vanschoenbeek, Novecento in Gent. De wortels van de sociaal-democratie in Vlaanderen (Antwerp: Uitgeverij Hadewijch, 1995). The Gentse Volkskinderen was an educational initiative for working-class children of socialist militants, founded in 1898. Boys and girls between the ages of 6 and 14 were taken on short and longer holiday trips. See: Bruno Vanobbergen and Frank Simon, “'Merci à tous et à toutes de votre propagande, si pleine de charme et de sourires': On Tour with the Socialist Travelling Colony Gentse Volkskinderen (1898-1915)," History of Education 40, no. 3 (2011): 315-332. 
ied the socialist model, but at the same time explicitily presented itself as 'antisocialist' ${ }^{70}$

\section{The outline of the volume and methodological perspectives}

The chapters in this book are grouped into three thematic sections. The authors of the research shaping part I, 'Social-pedagogical perspectives on the social question', are for the most part active at the Department of Social Work and Social Pedagogy of Ghent University. Social pedagogy has not been developed as a coherent system of theory building. In general, social pedagogical research deals with the relations between individuals and their social environment by paying special attention to the social preconditions for individual development and the pedagogic opportunities for influence and help. ${ }^{71}$ Chapters 2 and 3 focus on the mechanisms of spatial and ideological in- and exclusion and some of the paradoxes that characterised the process of educationalisation in the history of child care initiatives and leisure time associations in $19^{\text {th }}$-century Belgium.

In chapter 2, Lieselot De Wilde, Bruno Vanobbergen and Michel Vandenbroeck analyse three child welfare initiatives in Belgium within the broader European context of reformers who discussed the fate of the 'unfortunate children' of the working classes during international congresses. They show how educationalisation of the 'child at risk' went hand in hand with medicalisation, making the parents invisible. The late $19^{\text {th }}$-century medico-moral discourse considered unfortunate children to be both at risk and a future risk for society. De Wilde, Vanobbergen and Vandenbroeck's 'rhetorical' analysis of a selection of photographs of child care initiatives attests to how the visual turn in the humanities and social sciences has led to a methodological renewal in the history of education. Recent studies no longer consider the visual as a transparent source with a stable meaning, but consider photographs as complex objects in their material and affective qualities, shaped by historical circumstances. ${ }^{72}$

70 For the history of the Antisocialistische Werkliedenbond ('Anti-Socialist Workers' League'), founded in 1891, see: Strikwerda, A House Divided, 229-238.

71 Juha Hämäläinen, "Defening Social Pedagogy: Historical, Theoretical and Practical Considerations,” British Journal of Social Work 45 (2015): 1022-1038.

72 See: Inés Dussel and Karin Priem, “The Visual in Histories of Education: A Reappraisal," Paedagogica Historica 53, no. 6 (2017): 641-649; Inés Dussel, "The Visual Turn in the History of Education: Four Comments for a Historiographical Discussion," in Rethinking the History of 
In chapter 3, through a spatial micro-analysis, Evelyne Deceur, Maria Bouverne-De Bie and Angelo Van Gorp focus on the parallel pillarised social-cultural infrastructure set up by Catholics, liberals and socialists in one particular workers' neighbourhood in Ghent during the late $19^{\text {th }}$ to early $20^{\text {th }}$ centuries. They show how the raw materials for the construction of the future Catholic pillar were already in place well before the late 1870s, in the form of a network of Catholic social work, instructional and leisure-time bodies. The authors trace the historical roots of current participatory projects in urban renewal programs, where participants are seen as passive consumers instead of active co-designers and instrumental initiatives have become self-evident, to $19^{\text {th }}$-century pillarised socialcultural infrastructures.

The study of continuities and discontinuities in the development of educational practices is an important research line at different departments of Educational Sciences in Flemish universities. ${ }^{73}$ When comparing the two collective chapters of Part I, written by pedagogues/educationists, with the subsequent contributions of historians in the following sections, it becomes clear that there is still some kind of tension in the field of history of education between the applied interests of educationists specialised in history and the aspirations of historians to depict the past of educational and social reform on its own terms. ${ }^{74}$ Both chapters authored by historical educationists link history to current

Education. Transnational Perspectives on its Questions, Methods, and Knowledge, ed. Thomas S. Popkewitz (New York: Palgrave Macmillan, 2013), 29-49.

73 Frank Simon, trained as an historian, and Marc Depaepe, trained as an educator, have been working together for decades. As representatives of the universities of Ghent and Leuven, they have given the Belgian output within the field of history of education considerable weight abroad. At the Katholieke Universiteit Leuven, there is a special centre for the history of education, with large expertise in the history of educational initiatives for people with disabilities. Paedagogica Historica, an international journal in the history of education, was born in Ghent University in 1961. History of Education is still an important research line of the present-day Department of Social Work and Social Pedagogy at Ghent University. However, in some European countries the discipline of historical pedagogy is in a state of crisis, with educational scholars who have to increasingly re-orient themselves towards fields of more immediate practical concern. For the situation in Finland and France, see: Jukka Rantala, "History of Education Threatened by Extinction in Finnish Educational Sciences," and Pierre Caspard and Rebecca Rogers, "The History of Education in France: A Laboriously Useless Science," in Knowledge, Politics and the History of Education, ed. Jesper Eckhardt Larsen (Berlin: Lit Verlag, 2012), 25-39 and $73-87$.

74 For the difference between the attitudes towards past and present of historians and educationists in post-war England, see: William Richardson, "Historians and Educationists: the History of Education as a Field of Study in Post-war England. Part I: 1945-1972," History of Education 28, no. 1 (1999): 1-30; W. Richardson, "Historians and Educationists: the History of Education as 
social welfare issues, such as the continuous expansion of the child at risk and the instrumental use of participatory urban renewal programs, whereas historians tend to stay away from current debates. The authors of the two social-pedagogical contributions do not read present-day social arrangements back into history in search for origins, but they share a belief in the influence of deeply embedded historical and cultural habits on present-day social work practices, such as distinctions between 'deserving' and 'undeserving' parents and the conception of categories of children at risk. ${ }^{75}$ Both chapters assume that social work's past exists in its present through on-going aspects carried forward from each historical moment. ${ }^{76}$ Evelyne Deceur, Maria Bouverne-De Bie and Angelo Van Gorp explicitely use a 'history of the present'-approach, inspired by Foucault's use of history as a means of critical engagement with the present, in order to trace the historical power relations and struggles that gave birth to present-day practice. ${ }^{77}$

In Part II, 'New topics in the history of social and educational reform', three historians fill historiographical gaps by looking at some specific, under-researched aspects of the $19^{\text {th }}$-century 'bourgeois civilising offensive' in Belgium. All three chapters explore sources which have barely been used in earlier research. Chapters 4 and 5 focus on private initiatives in the battlefield of education. Private liberal fundraising for secularised schools in the 1870s and 1880s is well covered in Belgian historiography. ${ }^{78}$ In chapter 4, Stijn Van de Perre shifts the focus towards the social and economic aspects of an early under-researched fundraising initiative for Catholic schools: the Société Civile du Crédit de la Charité (1855). Van de Perre's research connects with a recent international interest in the economics of education and school funding among historians of education. In chapter 5, Christina Reimann explores the limited impact of Belgium's most visible liberal educational association, the Ligue de l'Enseignement (1864), in

a Field of Study in Post-war England. Part II: 1972-1996," History of Education 28, no. 2 (1999): $109-141$.

75 Walter Lorenz, "Practicising History. Memory and Contemporary Professional Practice," International Social Work 50, no. 5 (2007): 601.

76 John Harris, "State Social Work,” 662-679.

77 David Garland, "What is a 'History of the Present'? On Foucault's Genealogies and their Critical Preconditions,” Punishment \& Society, 16, no. 4 (2014): 365-384. For a genealogical research on Belgian child care history that starts from actual questions, see: Michel Vandenbroeck, "The Persistent Gap between Education and Care: a "History of the Present" Research on Belgian Child Care Provision and Policy,” Paedagogica Historica 42, no. 3 (2006): 363-383.

78 Jacques Lory, Libéralisme et instruction primaire, 1842-1879. Tome 2, 521-585; Frank Simon, “De vrije liberale school te Sint-Amandsberg (1886-1896)," Handelingen van de Maatschappij voor Oudheidkunde en Geschiedenis te Gent 31 (1977): 191-224. 
small villages and towns. The remarkable difference between the Belgian League's failure to integrate the countryside and the local success of the Education League in France is central in Reimann's argument. Although the Belgian Education League has been a subject of research since the 1970s, the local embeddedness of the Ligue has not yet been explored in detail.

Not only the financing and organisation of formal education, but also the quality and quantity of the food available to working-class families was a topic of great concern among European reformers. A couple of scholars have already made a link between people's kitchens in Amsterdam and Brussels, i.e. dining halls which offered workingmen a cheap but healthy lunch during their break, and a broader civilising offensive, but never in detail nor in a comparative manner. ${ }^{79}$ In chapter 6 , Jeffrey Tyssens reconstructs and compares the history of cheap popular restaurants started by social reformers in two Belgian and two Dutch cities in the last third of the $19^{\text {th }}$ century. He explains how these reformers wanted to organise modern alternatives to traditional charitable food distribution through "volksgaarkeukens" or "fourneaux économiques". However, these restaurants, just like the people's bank in Ghent described earlier, did not necessarily reach the workers with low incomes they were aiming for.

Tyssens' and Vandeperre's careful biographical reconstructions of the lives of Frederik Nysiemus Boer (1818-1915) and Ferdinand de Meeûs (1798-1861), reformers coming from completely different backgrounds, give us insights into the various possible motives and ideas behind reformist initiatives. Reimann, on the other hand, gives a voice to many unknown education activists in small Belgian towns and villages. Inspired by the work of educational theorist John Dewey, she places the 'experiences' of these militants at the centre of her chapter. The meticulous historical research of Reimann, Van de Perre and Tyssens clarifies why the Société Civile du Crédit de la Charité and the Ligue de l'Enseignement did not succeed in achieving a nationwide relevance, and why some people's restaurants fared better than others in the Low Countries. In the case of the Catholic fundraising initiative, the Société Civile du Crédit de la Charité failed to have a national impact because of the uncommon business-like approach used by its organisers to raise money and invest, whereas the Ligue de l'Enseignement suffered from a considerable social and cultural divide between the centre in Brussels and provincial circles. The success of cheap dining halls seemed to depend on the extent of competition with the boarding house sector and the size of the cities. Hope-

79 See: Smit, De Volksverheffers, 261-265; Jeffrey Tyssens, "Association, Patronizing and Autonomy: Belgian Masonic Lodges as Sponsors of a 'Cooperative' Movement in the 1860s and 1870s,” Journal for Research into Freemasonry and Fraternalism 2, no. 2 (2011): 261-292. 
fully these valuable findings can inspire others to conduct further historical research into battles around school financing, (failed) processes of educationalisation in rural areas and small towns and the importance of food in reformers' civilising mission, in Belgium as well as in other national contexts.

The chapters of part III focus on transnational connections and circulations of people and ideas. Lately, a lot of research has been conducted on the extent and variations of the transfer of ideas on social reform, which requires writing history from a transnational perspective. Transnational history pays attention to non-state actors that thrive between, across and through different nations. It thus focuses on movements, flows and the circulation of persons and ideas across borders. ${ }^{80}$ In the past few years, the historiography of social and educational reform in Belgium has benefited greatly from such a transnational turn. Historians have been focusing their attention on Belgian agency in international reform congresses and associations in order to reconstruct the formation of transnational personal networks and the transfer of ideas and practices. ${ }^{81}$

A focus on transfers and "histoire croisée" form the methodological core of history in a transnational perspective. ${ }^{82}$ In a 1994 article, French historian Michel Espagne put forth the concept of 'transfers' in his critique of classical comparison. He called for more room to be given to historical studies of transfers, since every nation is constituted not only by its own traditions, but also by transfers from other nations. ${ }^{83}$ French historian Michael Werner and his colleague Bénédicte Zimmerman reflected on the limits of comparative methods and transfer studies and introduced the term 'histoire croisée' in the debate on “relational approaches" in order to overcome linear analyses. The notion of an intersection is basic to the histoire croisée-approach. Within a histoire croisée, entities and objects of research are not merely considered in relation to each other, as in com-

80 See: Pierre-Yves Saunier, Transnational History (London: Palgrave Macmillan, 2013).

81 For a historiographical overview, see: Thomas D'haeninck, Lisa van Diem and Amandine Thiry, "Hervormers en de sociale kwestie in België tijdens de negentiende eeuw," Contemporanea 38, no. 4 (2016), http://www.contemporanea.be/nl/article/2016-4-review-dhaeninck-vandiem-en-thiry.

82 Philipp Ther, "Comparisons, Cultural Transfers, and the Study of Networks. Toward a Transnational History of Europe," in Comparative and Transnational History. Central European Approaches and New Perspectives, eds. Heinz-Gerhard Haupt and Jürgen Kocka (New York: Berghahn Books, 2010), 204.

83 Michel Espagne, "Sur les limites du comparatisme en histoire culturelle,” Genèses 17 (1994): $112-121$. 
parative and transfer studies, but also through one another, in terms of relationships, interactions, connections and circulation. ${ }^{84}$

A 2016 article by Carmen Van Praet analysed the transnational transfer and local adaption of housing models for the lower classes. ${ }^{85}$ This research was part of a larger research project of Liberas/Liberaal Archief in collaboration with Ghent University, dedicated to the transnational history of social liberalism. We chose to include a reprint of this article as chapter 7 for two reasons in particular. First, there is still an immediate need for concrete empirical research into entangled histories (including histoire croisée and transfer history) in order to avoid the methodological debate on relational approaches becoming lost in the abstract. ${ }^{86}$ Second, transnational influences played a vital role in the development of social policy. The transfer of practical solutions to the social question occurred through real-life podia, such as world exhibitions, national and international conferences, social institutions such as Toynbee Hall, personal contacts and professional networks. Social housing was a domain par excellence in which international congresses resulted in the transfer of ideas and formalisation of transnational contacts. ${ }^{87}$ Van Praet examines the origins of the housing model

84 Michael Werner and Bénédicte Zimmermann, "Beyond Comparison: Histoire croisée and the Challenge of Reflexivity," History and Theory 45, no. 1 (2006): 30 - 50.

85 Carmen van Praet, "The Opposite of Dante's Hell ? The Transfer of Ideas for Social Housing at International Congresses in the 1850 - 1860," Transnational Social Review. A Social Work Journal 6, no. 3 (2016): 242-261.

86 A recent successful example of an empirical study into transnational links and cross-border flows, in the field of urban reform, is Philipp Wagner's study on expert internationalism in the first half of the $20^{\text {th }}$ century. Wagner examines how the British garden city movement succeeded in influencing Belgian architects and politicians in the post-war reconstruction. He reveals how the First World War offered a unique window for British garden city supporters to influence national building laws across borders. See: Philipp Wagner, Stadtplanung für die Welt? Internationales Expertenwissen 1900-1960 (Göttingen: Vandenhoeck \& Ruprecht, 2016), 39-64, 78-90. For an entangled history of children's libraries in Belgium, see: Christophe Verbruggen, and Julie Carlier, “An Entangled History of Ideas and Ideals: Feminism, Social and Educational Reform in Children's Libraries in Belgium before the First World War," Paedagogica Historica 45, no. 3 (2009): 291-308.

87 Smit, Volksverheffers, 65-72. Smit gives the example of the travels of the Dutch physician Samuel Sarphati (1813-1866), who initiated reform initiatives in Amsterdam after having been inspired by foreign examples, such as the Brussels Musée de l'Industrie, and the visits of foreign guests to the workers' housing area of Jacques van Marken (1845-1906) in Delft. For an overview of the question of social housing in France, see: Roger-Henri Guerrand, "Espaces privés," in Histoire de la vie privée, volume 4. De la Révolution à la Grande Guerre, ed. Michelle Perrot (Paris: Le Seuil, 1987), 325-411. 
of a French house building association, the Société Mulhousienne des Cités Ouvrières in Mulhouse, and its transnational transmission and institutionalisation in various Belgian cities. She overcomes a linear transfer history by elaborating on the local adaptation of the housing model in Belgium, taking convergences, divergences and socio-economic and political factors that influenced local transformations into account. In other words, without explicitly mentioning the relational, interactive and process-oriented method defined by Werner and Zimmerman, Van Praet looks upon the history of social housing as a clear example of histoire croisée.

The study of 'networks', defined by Manuel Castells as a "set of interconnected nodes", makes it possible to conduct an empirical transnational study because it offers the opportunity to focus on institutionalised and consolidated forms of cultural exchange. ${ }^{88}$ In Chapter 8, Amandine Thiry, Thomas D'haeninck and Christophe Verbruggen conduct a quantative analysis of reformist networks by analysing the changes over time in the memberships of Belgian and Dutch actors in international organisations and conference series devoted to social and educational reform. The tools of a collaborative digital humanities project allowed them to map the number of Belgium-based international educational organisations, highlighting the pivotal role of Belgium in comparison with the Netherlands, as well as to analyse the co-presence of Belgians and Dutch at international congresses. This actor-oriented approach indicates that international educational congresses can not be separated from a wider network formed by international reformist congresses and are deeply rooted in transnational networks that emerged much earlier. Focusing on actors who connected different clusters of reform also enabled the authors to examine how 'educational internationalism' related to the emergence of an international movement for the protection of the child.

The analysis of the composition of social networks does not answer research questions about the intertwinement of local and international discursive fields in (changing) discourses. A biographical focus on the lives and thoughts of individual reformers enables us to gain a deeper understanding of the complex process of performing expertise and the mechanisms behind the cross-border circulation of knowledge. The intellectual mobility of one specific social reformer, the Ghent liberal Auguste Wagener (1829-1896), in a transnational network is at the centre of the contribution of Thomas D’haeninck (Chapter 9). Like many other reform-

88 Manuel Castells, "Materials for an Exploratory Theory of the Network Society," British Journal of Sociology 51, no. 1 (2000): 15; Ther, "Comparisons, Cultural Transfers, and the Study of Networks," 218. 
ers, Wagener proved to be a "rooted cosmopolitan" 89 who referred to both the local and the international levels to persuade various audiences. Wagener referred to ideas which circulated in transnational networks and the international prestige of local initiatives to gain legitimacy at home, while referring to his local and professional background to claim expertise on international fora. The intellectual mobility of Wagener illustrates that the transnational perspective cannot simply be considered as a simple change of focus, a supplementary level of analysis to be added to local, regional, or national levels. Far from being limited to a macroscopic reduction, the transnational should be apprehended as a level that exists in interaction with the others, producing its own logics with feedback effects upon other space-structuring logics. ${ }^{90}$

This volume certainly does not cover all aspects of social and educational reform in Belgium. For example, the question of the civilising offensive in the Congo colony and its impact on the metropole is not addressed and the role of social and educational reform initiatives in the preparation of the working classes for the future extension of suffrage is only tackled indirectly. However, each chapter is compelling in its own way and there are also a lot of interesting parallels between them. Together, these chapters stimulate the debate between historians and social pedagogues and place the history of social and educational reform in Belgium within a broader European perspective.

89 Rooted cosmopolitans are "people who are rooted in specific national contexts, but who engage in regular activies that require their involvement in transnational networks of contact and conflicts". See: Sydney Tarrow and Donatella della Porta, "Conclusion: Globalisation, Complex Internationalism and Transnational Contention,” in Transnational Protest and Global Activism, eds. Sydney Tarrow and Donatella della Porta (Lanham: Rowman \& Littlefield, 2005), 237.

90 See: Werner and Zimmerman, "Beyond Comparison: Histoire croisée and the Challenge of Reflexivity”. For more on the relationship between histoire croisée and the transnational dimension, see: Michael Werner and Bénédicte Zimmerman, "Vergleich, Transfer, Verflechtung. Der Ansatz der Histoire croisée und die Herausforderung des Transnationalen," Geschichte und Gesellschaft 28, no. 4 (2002): 607-636. 